\title{
KNOWLEDGE OF INTELLECTUAL PROPERTY AS A BASE FOR THE FORMATION OF FUTURE TEACHER'S LAW CULTURE
}

\author{
Avramenko Oleh, Doctor of Pedagogical Sciences, Professor, Pavlo Tychyna Uman State \\ Pedagogical University. \\ ORCID: 0000-0001-6594-801X \\ E-mail: aaaooobbb3@ukr.net
}

The article substantiates the need of basic knowledge on intellectual property as a necessary component of the teachers' legal culture formation.

The analysis of psychological and pedagogical literature on the peculiarities of the structure and content of students' at higher educational institutions knowledge of intellectual property gave the opportunity to develop methodological basis for the formation of basic knowledge about patent science, copyright and related rights. The aim is to prepare students for future professional activity, providing immersed knowledge and skills of their practical use.

The presented methodological foundations for the formation of basic knowledge of intellectual property and legal culture have found concrete implementation in the program of the discipline "Fundamentals of Intellectual Property". This technique will allow to realize the technology of formation of professional knowledge on copyright and related rights, patent science and, in general, will allow to implement technology of future teachers' legal culture formation of professional knowledge.

Keywords: knowledge, intellectual property, copyright, patent right, legal culture, teachers training, program, criteria for evaluating.

\section{ЗНАННЯ 3 ІНТЕЛЕКТУАЛЬНОЇ ВЛАСНОСТІ ЯК ОСНОВА ФОРМУВАННЯ ПРАВОВОЇ КУЛЬТУРИ МАЙБУТНЬОГО ПЕДАГОГА}

Авраменко Олег, доктор педагогічних наук, професор, Уманський державний педагогічний університет імені Павла Тичини.

ORCID: 0000-0001-6594-801X

E-mail: aaaooobbb3@ukr.net

У статті обтрунтована необхідність формування базових знань з інтелектуальної власності як необхідної складової формування правової культури педагогів, що обумовлено тісним зв'язком діяльності фахівців цієї галузі у науковому та навчальному процесі із застосуванням знань $в$ сфері патентознавства, авторського та суміжних прав. Аналіз психолого-педагогічної літератури щзодо особливостей структури $i$ змісту знань з інтелектуальної власності студентів вищих педагогічних навчальних закладів дав можливість розробити методичні засади формування базових знань з патентознавства, авторських та суміжних прав з метою підготовки їх до майбутньої професійної діяльності, забезпечивши поглибленими інтегрованими знаннями й навичками їх практичного застосування.

Представлені методичні засади формування базових знань з інтелектуальної власності та правової культури знайшли конкретне втілення в програмі навчальної дисципліни «Основи інтелектуальної власності». А також подані основні елементи иієё програми. Очікуваними результатами навчанням $\epsilon$ оволодіння такими фаховими компетентностями як знання 
основних понять системи правової охорони інтелектуальної власності; складових системи інтелектуальної власності в Украӥні; знання системи інтелектуальної власності в нормах загального законодавства Украӥни; знання об'єктів та суб'єктів права інтелектуальної власності. Майбутній педагог повинен вміти визначати алгоритм правової охорони об'єктів патентного права; вміти визначати алгоритм правової охорони об'єктів авторського права; вміти визначати права та обов'язки власників охоронних документів на об'єкти права інтелектуальної власності; вміти визначати вартість предмета лічензійного договору про передачу прав на використання об'єктів права інтелектуальної власності вміти визначати прочедуру захисту прав інтелектуальної власності у разі їх порушення тощо. Таким чином, дана методика дозволить реалізувати технологію формування професійних знань з авторських $i$ суміжних прав, патентознавства та, загалом, дозволить реалізувати технологію формування професійних знань правової культури майбутніх вчителів.

Ключові слова. знання,інтелектуальна власність, авторське право, патентне право, правова культура,підготовка вчителів, програма,критерії оцінювання.

In the context of globalization and rapid development of technologies, intellectual property becomes the main resource capable of ensuring the state's competitiveness. The intensification of innovation activity in all sectors of the country is a significant factor, which influences the rapid growth of the number of intellectual property objects. It causes the need to define, to structure, to evaluate, to account and to legally protect property rights. In the leading countries of the world intellectual property is regarded as one of the main components of the national wealth. For this reason, especially in the recent decades, special attention is paid to the protection of the rightful use of intellectual property in Western Europe and the United States. In the context of intensifying the development of the national innovation system as a direction of modernization and recovery of the Ukrainian economy, intellectual property also occupies a key position, which makes this research relevant for today.

Formation of basic knowledge on intellectual property is an important component of the future educators' training, since the activity of specialists in the scientific and educational process is closely related to the use of knowledge in the field of intellectual property, especially copyright. Thus, the richest woman in the UK (2002) was the writer Joanne Kathleen Rowling, who presented the world with Harry Potter. In one year she profited $€ 77 \mathrm{mln}$ from the sale of the rights to publish and screen her books. What is more impressive, the famous Microsoft ${ }^{\circledR}$ Corporation using such a copyright object as a computer program in a short time came out on the world's top in terms of the capital, and its founder Bill Gates is considered to be the richest man in the world.

Despite the importance of the problem addressed in this paper, an analysis of current practice in higher education leads to the conclusion that the formation of intellectual property competencies of future teachers is not well developed, what makes this research up to date.

Such scientists as N. Myronenko [4], E. Kokhanovska [3], M. Paladii [5], S. Poliakov [7] and others have worked on the problem of the analysis of intellectual property in Ukraine.

The writings of S. Sokolova [9], D. Ishchenko [2] are devoted to the analysis of the essence of right knowledge and justice; studies of the content and methods of their formation are accustomed to publications of M. Gorodyskyi [1]. The process of legal training of future teachers is substantiated in the work of M. Podberezskyi. Inspite of the great achievements of these researchers, their findings do not fully disclose the generalized vision of future educators' preparation to the formation of their intellectual property competencies.

In today's pedagogical context a legal culture of the teacher becomes personally and socially significant.

Legal culture is a prerequisite for the successful fulfillment of his professional 
functions - teaching and education are considered as integration or synthesis of innate and acquired personal properties that provide a high level of pedagogical activity. Legal personality culture characterizes the professional specialist in terms of personal socially meaningful and practical readiness for competently constructed professional activity on the basis of flexible self-realization of spiritual and creative forces of the personality.

Goals formulation: to describe the structure and place of intellectual property in the training of modern teachers.

Today the major task is the development of Ukraine based on an innovative model, which is rooted in the results of creative activity of citizens - the objects of intellectual property rights, to be more specific. At the same time, education in the field of legal protection, practical use and protection of intellectual property rights is far behind the today's needs. It requires the provision of appropriate knowledge and skills for students of higher education institutions, as future innovators. The Decree of the President of Ukraine "On Measures for the Protection of Intellectual Property in Ukraine" (dated April 25, 2001, № 285) serves as an evidence. The main task of the Decree is to introduce discipline in the basics of intellectual property in higher educational establishments.

The analysis of psychological and pedagogical literature on the peculiarities of the knowledge structure and content of students' intellectual property gave the opportunity to develop methodological outlines for the formation of basic knowledge on patent science, copyright and related rights. The aim of the analysis is to prepare them for future professional activity, providing with integrated abilities and skills of practical application. These ideas were externalized in the curriculum of the discipline "Fundamentals of Intellectual Property", developed by us in accordance with educational and professional training programs for specialists. Depending on the direction of training provided at higher education institutions, the ratio of hours between the sections of the course and between types of classes may change.

The main objectives of the course are to ensure the intellectual and social development of the individual by teaching the basics of the legal and economic aspects of protecting the rights of the individual to the results of intellectual activity.

The expected results of the training are mastering such professional competencies as:

- knowledge of the basic concepts of the system of legal protection of intellectual property;

- components of the intellectual property system in Ukraine;

- knowledge of the intellectual property system in the norms of the general legislation of Ukraine;

- knowledge of objects and subjects of intellectual property rights.

The future teacher should be able to determine:

- the algorithm for the legal protection of patent law objects (inventions, utility models, industrial designs);

- the algorithm of legal protection of copyright objects (works of literature, science and art);

- the rights and responsibilities of the owners of security documents for objects of intellectual property rights;

- the value of the subject of the license agreement on the transfer of rights to use the objects of intellectual property rights;

- the procedure for the protection of intellectual property rights in case of their violation, etc. 
The distribution and content of topics by training modules are presented in the program.

\section{The discipline program}

Module 1. Theoretical framework of intellectual property.

Content module 1. Basic principles of patenting and copyright.

Theme 1. Intellectual property as a right to the results of human creative activity.

The concept of intellectual property. Intellectual property as a result of creative activity. Intellectual property as a right. The evolution of intellectual property. The evolution of industrial property. The evolution of copyright and related rights. The evolution of intellectual property in Ukraine. The place and role of intellectual property in the economic and social development of the state. Socio-economic strategies in countries of world society. The role of industrial property in economic development. Copyright and cultural development.

Theme 2. Intellectual property system.

Objects of intellectual property rights. Classification of objects of intellectual property rights. Objects of industrial property. Non-traditional intellectual property objects. Objects of copyright and related rights. Subjects of intellectual property rights. Creator (author) as a subject of law. Citizens, juristic parties and the state as subjects of intellectual property rights. Subjects of industrial property rights. Subjects of copyright. Subjects of related rights. Ukrainian legislative system on intellectual property. Constitution of Ukraine. Norms of Civil, Economic and Criminal Codes of Ukraine on Intellectual Property. Special legislation of Ukraine on intellectual property issues. International agreements on intellectual property. Ukraine's membership in international treaties on intellectual property. World Intellectual Property Organization, its structure and main functions. International cooperation within the framework of regional intellectual property treaties.

Content module 2. Conservation and protection of intellectual property rights.

Theme 3. Aims and principles of legal protection.

The purpose of legal protection. Principles of legal protection of intellectual property objects. Protection of industrial property rights.

The demand for legal protection of intellectual property rights. The acquisition of rights to inventions and utility models. Options for legal protection decisions. Conditions of patentability of the invention (utility model). Patenting procedure. The term of the patent. Early termination of the patent. Rights of the patent holder. Acquisition of industrial design rights and geographical indications. The procedure of obtaining the security document for the industrial design. The procedure for obtaining a geographical indication.

Trademark Acquisition. The procedure of obtaining a security document for a trademark. Protection of copyright and related rights.

Topic 4. Economics of Intellectual Property.

Intellectual property rights as a commodity. Features of intellectual property rights as a commodity. Intellectual property as an intangible asset. Commercialization of intellectual property rights. Purposes and methods of commercialization. The concept of intellectual capital. Use of the objects of intellectual property right in own production. Introduction of intellectual property to the authorized capital of the enterprise. Assignment of intellectual property rights. Transfer of intellectual property rights: under a license agreement, under a commercial concession agreement, under a lease agreement. The essence of license trading. Types of licenses. License agreements. Valuation of intellectual property rights.

Theme 5. Protection of Intellectual Property Rights. 
Intellectual property rights protection system and its purpose. Reasons for violation of rights. Purpose of the system of intellectual property rights protection. Actions regarded as infringement of intellectual property rights. Actions that violate the rights of owners of industrial property. Major violations of copyright and related rights. Forms, procedures and methods of protection of intellectual property rights.

Jurisdictional form of protection. Non-jurisdictional form of protection. Types of violations of rights that are considered administratively. Civil Procedure for the Protection of Rights. The procedure for the protection of violated rights established by the criminal law. Responsibility for violation of rights stipulated by the Criminal Code of Ukraine.

Module 2. Individual Research Task (IRT)

Topics for practical assignments:

Intellectual property as a right to the results of human creative activity. Intellectual property system. Purpose and principles of legal protection. Economics of Intellectual Property. Protection of intellectual property rights.

Individual task:

Formation and development of the legislation of Ukraine on intellectual property. General provisions of the legislation of Ukraine on intellectual property. Copyright and patent law: commonality and difference. Public Administration of Intellectual Property. Copyright agreements. Terms. Contracts in the field of scientific and technical activities. Contracts for the use of industrial property. License agreements.

Conditions of patenting of industrial property objects in foreign countries. Collective management of intellectual property rights under the WIPO Model Law. Intellectual property representatives. State Intellectual Property Inspectors. International conventions on the protection of copyright and related rights.

Module 2. Individual tasks.

1. Intellectual activity and its place in the socio-economic development of society.

2. Types of intellectual activity.

3. Features of literary activity.

4. Scientific and technical activities.

5. Means of individualization of participants of civil turnover, goods and services.

6. Formation of system of legal protection of results of intellectual property.

7. Formation and development of the legislation of Ukraine on intellectual property.

8. General provisions of the legislation of Ukraine on intellectual property.

9. Copyright and patent law: commonality and difference.

10. Public Administration of Intellectual Property.

11. Objects of scientific discoveries.

12. Objects of rationalization proposals.

13. Objects of protection against unfair competition.

14. Authors - creators of objects of intellectual property rights.

15. Assignees as subjects of intellectual property rights.

16. The emergence of intellectual property rights in works of science, literature, art and objects of related rights.

17. Registration of intellectual property rights on industrial property objects.

18. Application for the means of individualization of participants of civil turnover, goods and services

19. Issuance of a security document for an intellectual property object. 
20. Personal non-proprietary intellectual property rights to the intellectual property objects.

21. Proprietary rights on intellectual property of authors of scientific works, literature, art, related rights and subjects of industrial property.

22. Termination of legal protection of industrial property rights.

23. Termination of legal protection of means of individualization of participants of civil turnover, goods and services.

24. Termination of legal protection of a trademark.

25. Copyright agreements. Terms.

26. Contracts in the field of scientific and technical activities.

27. Contracts for the use of industrial property. License agreements.

28. Conditions for patenting industrial property objects in foreign countries.

29. Collective management of intellectual property rights under the WIPO Model Law.

30. Intellectual Property Representatives.

31. State Intellectual Property Inspectors.

32. Civil protection of intellectual property rights.

33. Criminal protection of intellectual property rights.

34. Administrative and legal protection of intellectual property rights.

35. Intellectual property as a component of intellectual capital in economic sense.

36. Valuation of intellectual property value.

37. The mechanism of commercialization of intellectual property.

38. Taxation of transactions with intangible assets.

39. General International Agreements on Intellectual Property. World Intellectual Property Organization (WIPO).

40. International conventions on the protection of copyright and related rights.

41. International legal protection of industrial property.

42. International legal protection of the means of individualization of the participants of the civil turnover, goods and services. International legal protection of trademarks.

43. State stimulation of intellectual activity.

44. Benefits for participants in intellectual activity.

\section{Criteria for evaluating learning outcomes}

Non-satisfactory level: The student gives an answer that is not directly relevant to the question, fragmentary reproduces a small part of the material, has a superficial idea of the object of study, expresses an opinion without a logical sequence.

Satisfactory level: Possession of educational material at the reproductive level. The student can reproduce much of the material, partly justifying and analyzing it, drawing conclusions.

Sufficient level: The student is able to reproduce the studied material, gives thorough answers to the questions and applies theoretical knowledge independently to accomplish educational tasks. The answer is complete, logical, reasonable but with some inaccuracies.

High level: The student has a deep, solid knowledge; can generalize, systematize; answers questions in a reasonable manner; is able to use the knowledge gained in his answers; shows creativity during reproduction of the acquired theoretical knowledge; clearly formulates conclusions with practical examples of theoretical material.

To sum up, in the modern period of development in Ukraine, the main social purpose of the state scientific, technological and innovation policy is to ensure the progressive 
development of society by maintaining the necessary scientific and technical potential of the nation for this level, using scientific discoveries, highly effective inventions to solve the problems of the present and future state, ensuring mutually beneficial exchange (transfer) of technologies in the conditions of world division of labor. Thus, we believe that the introduction into the educational process of a special discipline "Fundamentals of Intellectual Property" will allow to implement the technology of formation of professional knowledge of copyright and related rights, patent science and, in general, will allow to implement the technology of formation of professional knowledge of the legal culture of future teachers.

\section{СПИСОК ВИКОРИСТАНИХ ДЖЕРЕЛ}

1. Городиський М. І. Шляхи формування правової культури. Теорія і практика формування правової компетентності суб’єктів пед. процесу: зб. наук. пр. Х., 2000. С. 17-24.

2. Іщенко Д. В. Формування правової культури: теоретичні засади. Педагогічні науки. 2010. № 47, ч. II. C. $15-18$.

3. Кохановська О. Основні теорії права інтелектуальної власності та їх вплив на розвиток сучасного законодавства в Україні. Право України. 2011. № 5. С. 52-59.

4. Мироненко Н. Захист прав на торговельні марки: українська практика та європейський досвід. Право Украӥни. 2011. № 3. С. 30-39.

5. Паладій М. Удосконалення державної системи правової охорони інтелектуальної власності важлива складова інноваційного розвитку України. Інтелектуальна власність. 2010. № 4. С. 9-21.

6. Подберезський М. К. Правова культура майбутнього вчите ля (теоретико-методологічний аспект): монографія / за ред. акад. АПН України, д-ра пед. наук, професора I. Ф. Прокопенко. Харків: Основа, 1997. 220 с.

7. Поляков С. Ю., Куртов А. І., Нікітюк О. Б., Зміївський Г. А. Деякі аспекти та принципи управління інтелектуальною власністю в Україні. Вісник НТУ «ХПI». 2010. № 60. С. 72-83.

8. Правова культура як основа розвитку майбутніх інженерів-педагогів. Вісник Чернігівського національного педа гогічного університету імені Т. Г. Шевченка. URL: http://bo0k.net/index. php? $=$ achapter\&bid $=15119 \&$ chapter $=1$

9. Соколова С. В. Формування правової культури майбутніх інженерів-педагогів у вищих технічних навчальних закладах: дис. ... канд. пед. наук: 13.00.04. Київ, 2016. 313 с.

\section{REFERENCES}

1. Horodyskyi, M. I. (2000). Shliakhy formuvannia pravovoi kultury. Teoriia $i$ praktyka formuvannia pravovoi kompetentnosti subiektiv ped.protsesu. Kharkiv, 17-24 [in Ukrainian].

2. Ishchenko, D. V. (2010). Formuvannia pravovoi kultury: teoretychni zasady. Pedahohichni nauky, 47, ch. II, 15-18 [in Ukrainian].

3. Kokhanovska, O. (2011). Osnovni teorii prava intelektualnoi vlasnosti ta ikh vplyv na rozvytok suchasnoho zakonodavstva v Ukraini. Pravo Ukrainy, 5, 52-59 [in Ukrainian].

4. Myronenko, N. (2011). Zakhyst prav na torhovelni marky: ukrainska praktyka ta yevropeiskyi dosvid. Pravo Ukraina, 3, 30-39 [in Ukrainian].

5. Paladii, M. (2010). Udoskonalennia derzhavnoi systemy pravovoi okhorony intelektualnoi vlasnosti vazhlyva skladova innovatsiinoho rozvytku Ukrainy. Intelektualna vlasnist, 4, 9-21 [in Ukrainian].

6. Podberezskyi, M. K. (1997). Pravova kultura maibutnioho vchytelia (teoretyko-metodolohichnyi aspect). I. F. Prokopenko (Ed.). Kharkiv: Osnova [in Ukrainian].

7. Poliakov, S. Yu., Kurtov A. I., Nikitiuk O. B., Zmiivskyi H. A. (2010). Deiaki aspekty ta pryntsypy upravlinnia intelektualnoiu vlasnistiu v Ukraini. Visnyk NTU “KHPI”, 60, 72-83 [in Ukrainian].

8. Pravova kultura yak osnova rozvytku maibutnikh inzheneriv-pedahohiv. Visnyk Chernihivskoho natsionalnoho pedahohichnoho universytety imeni T. H. Shevchenka. URL: http://bo0k.net/index.php?p= achapter\&bid=15119\&chapter=1 [in Ukrainian].

9. Sokolova, S. V. (2016). Formuvannia pravovoi kultury maibutnikh inzheneriv-pedahohiv u vyshchykh tekhnichnykh navchalnykh zakladakh. Candidate's thesis. Kyiv [in Ukrainian]. 